\title{
PENERAPAN FINANCIAL PARENTING (GEMAR MENABUNG) PADA ANAK USIA DINI \\ Oleh
}

Astrid Krisdayanthi

astridkrisdayanthi@gmail.com

Dosen Dharma Duta IHDN Denpasar

\begin{abstract}
ABSTRAK
Pada masa keemasannya, anak sangat mudah dalam menyerap informasi. Orang tua memiliki tanggung jawab penuh dalam perkembangan anak dimasa keemasnnya ini. Tanggung jawab orang tua tidak sekedar membesarkan anak secara fisik, materi dan emosional saja, orang tua juga perlu menanamkan nilai-nilai kehidupan sebagai bekal untuk perkembangan anak, seperti mengajarkan tentang kecerdasan financial pada anak dalam mengelola keuangannya dengan cara menabung. Kebebasan financial yang diraih anak dimasa depan, adalah buah dari apa yang ditanamkan dan diajarkan oleh orang tuanya dimasa lalu.
\end{abstract}

Keyword: financial parenting, pengelolaan keuangan, anak usia dini, gemar menabung

\begin{abstract}
In its golden age, children are very easy to absorb information. Parents have full responsibility for developing children in their golden age. The responsibility of parents is not just raising children physically, materially and emotionally, parents also need to instill life values as a provision for children's development, such as teaching about financial intelligence to children in managing their finances by saving money. Children who achieved financial freedom in the future, is the result of instilled and taught by his parents in the past.
\end{abstract}

Keyword: financial parenting, financial management, childhood, save money

\section{PENDAHULUAN}

Anak usia dini adalah anak yang memiliki rentang usia 0-8 tahun dan sedang mengalami proses perkembangan fundamental yang sangat pesat dalam kehidupannya (Berk, 1995).
Pendidikan Anak Usia Dini adalah bentuk penyelenggaran pendidikan pada anak yang menitikberatkan pada perkembangan fisik, pertumbuhan kecerdasan anak baik secara emosional maupun spiritual, sosio emosional, bahasa dan komunikasi, yang disesuaikan 
dengan tahapan dan keunikan dari setiap perkembangan anak usia dini (Sujiono, 2011).

Orang tua dalam kamus besar Bahasa Indonesia adalah yang dimaksuddengan ayah dan ibu kandung yang pertama kalidikenal oleh anak-anaknya. Orang tua merupakan pendidik pertama dan utama yang memberikan pendidikan kepada anak- anak mereka dikarenakan melalui orang tualah anak-anak menerima pendidikan pertamakalinya. Orang tua dalam satu keluarga merupakan salah satu tempat belajar dan pembentukan karakter dari anak lahir sampai anak menjadi dewasa dan siap menjalanihidupnya sendiri. Anak akan diajarkan mengenai berbagai hal dalam hidupnya sebagai modal baginya dikemudian hari guna mewujudkan kesejahteraandan kemandiriannya kelak. Keluarga merupakan lembaga pendidikan yang bersifat informal, yang pertama dan utama dialami oleh anak. Orang tua memiliki tanggung jawab penuh dalam perkembangan anak. Tanggung jawab orang tua tidak sekedar membesarkan anak secara fisik, materi dan emosional saja, orang tua juga perlu menanamkan nilai-nilai kehidupan sebagai bekal untuk perkembangan anak, sepertimengajarkan tentang kecerdasan finansial anak dalam mengelola keuangannya dengan cara menabung. Orang tua berperan penting dalam menanamkan kebiasaan anak untuk menabung sejak dini. Jika sejak usia dini anak-anak diajarkan tentang kebiasaan menabung, maka kebiasaan menabung ini akan terus terbawa hingga anak tumbuh dewasa.

Anak dalam hal ini adalah manusia yang memilikisiklus hidupnya tersendiri. Sehingga apa yang ditanamkan dan diajarkan sekarang menjadi penentu kesejahteraan anak tersebut nanti. Kebebasan financial yang diraih anak dimasa depan, adalah buah dari apa yang ditanamkan dan diajarkan oleh keluarga dalam hal ini orang tuanya dimasa lalu. Orang tua yang memberikan contoh serta mengajarkan gerakan gemar menabung sedari dini akan bisa menciptakan anak yang lebih berhasil mencapai kebebasan financial dibandingkan dengan anak yang sedari kecil diberikan contoh konsumtif oleh orangtuanya.

Beverly dan Clancy (2001) mengatakan bahwa pendidikan keuangan dalam keluarga sangat dibutuhkan guna menjadikan anak individu yang cerdas dalam pengelolaan uang, tidak boros dan gemar menabung. Keluarga dalam hal ini orang tua sering sekali tidak memberikan contoh yang tepat, seperti sering terlihat konsumtif, tergoda membelibarang yang tidak diperlukan karena diskon, membelikan apa saja yang diminta anak hanya agar anak tidak menangis, dan masih banyak contoh-contoh lain yang sekiranya tidak tepat untuk dipertontonkan kehadapan anak-anak, karena hal itu hanya akan menghambat tumbuhnya kemampuan mengatur uang pada anak.

Pengelolaan keuangan perlu diperkenalkan dan diajarkan kepada anak sedini mungkin dengan tujuan anak memiliki pengetahuan yang tepat, bagaimana memanfaatkan dan mengelola uang yang mereka punya. Tentu saja sesuai dengan tahapan perkembangan anak. Anakanak yang sudah sejak awal diajarkan pola pembiasaan konsumtif oleh orang tuanya sulit dihentikan. Hal ini akan tercermin dari pola kebiasaan berbelanja anak yang sulit dihentikan. Sedangkan anak yang dari awal telah dibiasakan berhemat dan belajar menabung akan menujukkan pola kebiasaan yang tidak konsumtif dan cenderung akan lebih bisa mengatur uangnya. 
Menabung merupakan proses mengumpulkan dana dalamkurun waktu tertentu demi suatu tujuan. Orang tua dalam hal ini memiliki peran penting dalam menanamkan kebiasaan menabung pada anak. Setyaka (2014: 13) menjelaskan bahwa segala sesuatu yang dikerjakan akan membentuk sebuah kebiasaan, dan kebiasaan itulah yang akan menentukan jenis hasil seperti apa yang akan didapatkan. Hal ini didukung oleh pendapat Hill (2010: 4), bahwa menabung adalah semata-mata kebiasaan. Seorang anak yang sejak kecil dibiasakan untuk menabung, akan tumbuh menjadi anak yang gemar menabung dan disiplin mengenai keuangan saat dewasa nanti. Kedisiplinan anak untuk rajin menabung ini merupakan kebiasaan yang baik bagi perkembangan anak. Mengajarkan anak menabung sejak usia dini merupakan salah satu bentuk penerapan pengelolaan keuangan yang efektif guna menjadikan anak sosok yang penuh perencanaan terutama dalam hal keuangan dimasa depan.

Mengacu pada keseluruhan penjelasan sebelumnya tampak bahwa pendidikan tentang pengelolaan keuangan sangat dibutuhkan untuk meminimalisir kemiskinan dalam hal ini kemiskinan akibat pola hidup konsumtif, dan peran orangtua dalam hal ini menjadi sangat penting. Namun dewasa ini, tidak semua orang tua tidak semua anak memiliki pendidikan keuangan yang memadai. Dalam arti, tidak semua orangtua mampu mendiskusikan dan mengajarkan tentang cara mengelola uang yang benar pada anak sebagai salah satu modal mencapai kesejahteraan saat dewasa nantinya. Untuk itu, tulisan ini akan mengkaji penerapan financial parenting dengan metode gemar menabung pada anak usia dini yang diterapkan oleh orang tua sebagai salah satu modal mencapai kebebasan keuangan.

\section{PEMBAHASAN}

\subsection{Pendidikan Keuangan}

Olive, O'Rourke, dan Collins (2011) menjelaskan pendidikan keuangan dibutuhkan untuk mampu mendorong orang tua mengelola uang dengan benar. Orang tua yang mengerti menganai pendidikan keuangan akan lebih mampu mengajarkan anaknya dalam pengelolaan keuangan dibandingkan yang tidak terdidik. Hal ini berkaitan dengan orang tua sebagai contoh yang akan ditiru oleh anak, dimana pendidikan awal dari seorang anak adalah dimulai di keluarga dalam hal ini dimulai oleh orang tuanya sendiri.

Anak sedarikecil hendaknya diperkenalkan dengan uang. Bukan diperkenalkan hanya sebagai alat untuk membelikeinginannya semata, tetapi lebih dari itu agar anak lebih menghargai makna dari uang tersebut. Tidak hanya sebagai alat jual beli tetapi ada makna lebih tinggi lagi dari uang, yaitu sebagai alat membantu sesama dan berderma (dana punia). Selanjutnya agar anak tahu bahwa uang tidak datang tiba-tiba, tetapi hasil dari kerja keras orang tuanya guna mencukupi kebutuhannya. Diharapkan berdasarkan hal tersebut anak akan lebih menghargai jerih payahorangtuanya dengan cara berhemat dengan uang. Dan terakhir agar anak bijak dalam menggunakan uang

Danes (1994) dalam Sabri, McDonald, Hira dan Masud (2010) menyatakan bahwa kebanyakan dari orangtua berpikir bahwa anakanak sebaiknya diajarkan tentang cara mengelola uang saat berusia 18 tahun atau lebih. Hal ini merupakan kekeliruan orang tua dalam 
memulai mengajarkan mengelola uang pada anak. Mengajarkan pengetahuan pengelolaan keuangan pada anak seharusnya dimulai sejak dini agar hal tersebut menjadi suatu kebiasaan dan anak akan memiliki pola pikir yang tepat dalampengelolaan uang yang dimilikinya.

Pola komunikasi antara anak dengan orang tua menjadi dasar dalam keberhasilan penerapan financial parenting pada anak usia dini. Anak dengan pola komunikasi yang baik akan dengan leluasa menanyakan tentang kebingungannya dalam mengelola uang, sedangkan anak yang pola komunikasinya tidak harmonis akan canggung untuk bertanya dengan orang tuanya. Ketika orang tua gagal dalam membangun komunikasi dan memberi teladan kepada anak, maka akan adanya kecenderungan anak tidak menghargai uang. Perilaku ini pun akan menjadi kebiasaan mengelola uang hingga dewasa. Jadi tidak mengherankan jika anak yang sedari dini tidak mendapat pengetahuan yang baik tentang pengelolaan keuangan akan tumbuh dewasa dengan kurang ahlinya mengatur keuangan dan akan berdampak pada kemungkinan mengalami kesulitan financial dimasa tuanya/saat pensiun kelak.

Orang tua dimasa sekarang ini dituntut tidak hanya sekedar kekayaan materi saja pada anak, melainkan yang terpenting adaah memberikan kekayaan edukasi yang berguna untuk kelangsungan hidupnya kelak, dalam hal ini edukasi mengenai pengelolaan uang yang benar. Apabila sewaktu kecildiajarkan mengelola uang yang benar seperti berhemat, tidak pelit, gemar menabung, maka sampai dewasa hal itu yang akan tertanam dan menjadi pola pikir anak tersebut. Sejalan dengan Klontz (2009) bahwa pengalaman seseorang merupakan penentu perilaku keuangannya. Pengalaman yang didapat anak sejak kecil mengenai pengelolaan uang akan sangat berhubungan dengan perilaku keuangannya saat dewasa kelak. Anak akan tumbuh menjadi pribadi yang bertangung jawab dan mandiri dalam keuangan. Hal itulah yang akan menjadi pembeda antara individu satu dengan lainnya saat dewasa mengenai perilaku keuangannya.

Kesalahan orang tua dalam mendidik anak mengenaipengelolaankeuangan adalah Pertama, membiasakan anak-anak hidup menghamburhamburkan uang untuk tujuan bersenang-senang dan konsumtif. Dengan kata lain, membangun kebiasaan anak untuk mengadopsi pola pikir preferensi waktu positif. Dampak dari kesalahan ini adalah anak akan tumbuh menjadi individu yang suka menghambur-hamburkan uang dan menyukai kemewahan, hanya mementingkan keinginan sendiri tanpa mempedulikan kepentingan orang lain. Kedua, orang tua yang selalu menuruti permintaan anaknya. Hal ini akan berdampak pada anak yang tidak akan bisa menghargai nilai uang dan bagaimana cara mendapatkan uang atau anak tidak akan bisa menggunakan uang secara tepat, dikarenakan apa yang diminta selalu terpenuhi secara cumacuma. Ketiga, memenuhipermintaan anak ketika menangis, terutama anak yang usianya masih kecil. Hal ini akan mengakibatkan anak memiliki sifat yang manja dan tidak memiliki kepercayaan diri. Keempat, jangan pelit pada anak melebihi batas kewajaran. Hal ini akan mengakibatkan anak menjadi kurang terpenuhi kebutuhannya dan menjadikan akan sewaktu dewasa akan menghalalkan berbagai macam cara untuk memeroleh uang, guna memenuhi keinginannya. Oleh karena itu, orang tua hendaknya dalam memberikan uang atau membelikan sesuatukepada anak agar selalu menjelaskan 
mengapa melakukan hal tersebut. Selain agar anak paham akan alasan orang tuanya membelikan sesuatu atau memberikan uang, hal ini juga bentuk pengajaran keterbukaan kepada anak. Agar kelak anak menjadi terbuka dengan orang tuanya mengenai keuangannya. Perilaku sederhana ini jika dilakukan secara terus menerus dan berkesinambungan akan berdampak signifikan pada perkembangan anak mengenai pengelolaan keuangan.

\subsection{Metode Gemar Menabung}

Apel jatuh tidak jauh dari pohonnya yang berarti seorang anak akan mengikuti perilaku yang dicontohkan orang tuanya, mulai daro cara berbicara, bersikap, berpikir, bahkan hingga cara mengelola uangnya (Seto, 2012). Menurut kamus besar Bahasa Indonesia menabung memiliki kata dasar tabung, yang mana kata menabung dapat diartikan sebagai sebuah tindakan, keberadaan, maupun pengalaman. Dalam pengelolaan keuangan, kebanyakan orang tua menggunakan metode menabung sebagai penerapan pengelolaan keuangan anak. Tidak semua anak bisa menerima kegiatan menabung sebagai bentuk edukasi, melainkan dengan pola komunikasi yang salah anak mungkin akan menganggap kegiatan menabung adalah salah satu bentuk hukuman/pembatasan mereka dalam penggunaan uang yang dimiliki untuk pemenuhan keinginannya. Demi meminimalisir terjadinya pemikiran negative dari anak, orang tua dapat menerapkan dua strategi yaitu strategi dengan menjadikan menabung sebagai kegiatan yang menyenangkan dan strategi dengan menetapkan tujuan menabung (Seto, 2012: 92). Strategi pertama meliputi beberapa cara, yaitu; a) Menyiapkan celengan dengan bentuk yang menarik dan unik yang disukai oleh anak. Celengan tersebut dapat berbentuk unik, menarik dan sesuai dengan kegemaran anak. Contohnya berbentuk seperti boneka, mobilmobilan, sepatu, kaleng yang ditempeli stiker karakter favorit anak dan ada juga celengan yang memiliki kunci yang dapat dibuka sewaktu-waktu;

b) Setiap pagi, setelah anak mendapat jatah uang saku, ayah atau ibu mendahului mengisi celengan di depan anak. Uang saku yang diberikan pada anak umumnya nominalnya tidak besar. Pemberian uang saku ini diharapkan anak mampu mengelola dan mengatur pengeluarannya baik untuk ditabungkan maupun dibelanjakan. Orang tua yang mengisi celengan anak didepan anaknya dengan harapan anak akan tergoda untuk mau menyisihkan uang sakunya tersebut untuk ditabung sebelum dibelanjakan nantinya disekolah;

c) Guna meningkatkan semangat menabung pada anak orang tua menawarkan hadiah yang diminta anak. Pemberian reward kepada anak yang memiliki tabungan banyak itu sebagai salah satu bentuk penghargaan dari orang tua pada anak yang telah berusaha untuk menyisihkan uang sakunya untuk ditabungkan. Reward bisa berupa tambahan uang saat anak akan membeli barang yang diiinginkan dengan menggunakan uang tabungan yang dimilikinya; 
d) Uang yang ditabungkan tidak harus langsung dari orang tua. Saat anak mendapatkan uang dari sanak saudara lainnya seperti paman, bibi, kakek, maupun nenek, maka anak tersebut memiliki hak atas uang itu. Anak memiliki hak penuh untuk membelanjakan maupun menabung uang tersebut. Bagianak yang mengerti nilai uang ia tidak akan menghabiskan uang tersebut cuma-cuma, ia biasanya akan membaginya atau akan menabungkan semuanya kedalam celengannya;

e) Menceritakan pengalaman orang sukses dengan rajin menabung, bekerja dan banyak berdoa adalah salah satu cara yang bisa digunakan untuk meningkatkan pemahaman anak akan pentingnya menabung. Cerita tersebut bisa memalui cerita di televisi, di internet atau bahkan cerita tentang keluarga yang telag berhasil membeli sesuatu akibat dari rajin menabung. Cerita tersebut dirasa akan menjadi motivasianak gunalebihsemangat untuk menabung;

f) Anak bisa menabung dengan cara mencontoh teladan dari orang tua. Anak merupakan peniru ulung orang tuanya. Jadi apa yang dilakukan orang tua, biasanya anak akan sangat mudah menirukannya. Orang tua dalam hal ini harus memberikan contoh dalam menabung, baik itu didalam celengan maupun mengajak anak untuk menemani orang tua menabung dibank. Hal ini akan sangat membantu anak untuk lebih cepat memahami bawa menabung itu penting bagi kehidupannya. Tidak disarankan jika orang tua hanya memaksa anaknya untuk menabung, sedangkan ia mencontohkan perilaku konsumtif didepan anaknya.

Strategi kedua yaitu menetapkan tujuan menabung. Menetapkan tujuan menabung yang dimaksud adalah orang tua mengajak anak menentukan untuk apa ia akan menabung. Dengan adanya tujuan yang jelas, anak akan termotivasi untuk menabung guna mewujudkan keinginannya. Menabung tanpa menetapkan tujuan yang pasti hanya akan dianggap tidak penting oleh anak, terutama bagi anak yang masih berusia dini. Berdasarkan hal tersebut, maka penting membuat anak merasa menabung merupakan kegiatan yang penting dan harus ia lakukan dengan menentukan tujuan yang pasti yang ingin anak capai menggunakan uang tabungan yang terkumpul tersebut.

Selain mengajarkan anak untuk menabung di rumah, orang tua juga mengajarkan anak untuk menabung di sekolah. Pihak sekolah dewasa ini biasanya memiliki fasilitas menabung untuk siswa dengan memberikan buku tabungan yang tertulisi nominalangka tabungannya. Orang tua dapat mendorong anak untuk menabung disekolah dengan menggunakan sisa uang saku yang dimilikinya atau mungkin dengan memberikan uang ektra khusus untuk ditabungkan anak disekolah. Selain itu, pihak sekolah juga hendaknya menghimbau siswa untuk menabung dengan menyisihkan uang sakunya agar terjalin korelasi antara apa yang diajarkan dirumah dengan disekolah, sehingga terjalin controlsosial yang baik antara orang tua dan sekolah. 


\section{PENUTUP}

Berdasarkan pembahasan diatas bisa ditarik kesimpulan bahwa penerapan financial parenting perlu diterapkan sejak anak usia dini, dikarenakan dengan terbiasanya anak mengelola uang sejak kecil, maka akan berdampak positif pada pengelolaan keuangannya saat dewasa nanti. Anak dengan pendidikan pengelolaan keuangan yang memadai akan sangat kecil kemungkinnya mengalami masalah keuangan disaat dewasa. Selain itu, dengan penerapan metode gemar menabung pada anak usia dini merupakan kegiatan yang positif dan sangat membantu dalam pengelolaan keuangannya dimasa depan. Strategi orang tua dalam menanamkan kebiasaan anak untuk rajin menabung di rumah dengan cara menggunakan strategi menabung sebagai kegiatan yang menyenangkan dan strategi menetapkan tujuan menabung. Dengan diterapkannya strategi tersebut diharapkan anak akan belajar untuk lebih menghargai uang, serta anak akan belajar untuk memenuhi keinginannya sendiri dengan cara menabung. Hal ini diharapkan akan berdampak pada terciptanya kemandirian dan rasa tanggung jawab anak.

\section{DAFTAR PUSTAKA}

Berk L.E. dan A. Winsler. 1995. Scaffolding Children Learning: Vygotsky and Early Childhood Education. Washington, DC: NAEYC

Beverly, S. \& Clancy, M. 2001. Financial Education in a Children and Youth Savings Account Policy
Demonstration: Issues and Options.

Research Background Paper 01-5

Hill, N. 2010. Hukum Sukses tentang Memelihara Kebiasaan Menabung serta Inisiatif dan Kepemimpinan. Tangerang: Karisma Publishing Group

Klontz, B, \& Klontz, T. 2009. Mind Over MoneyMengatasi Kelainan Keuangan Yang Menggerogoti Kesehatan Finansial. Jakarta: Penerbit Elex Media Komputindo

Olive, P. O'Rourke, C. \& Collins, J. M. 2011. Money \$mart in Head Start: Financial Education and Outreach with Head Start Families. CFS Issue Brief 20116.2

Sabri, M. F. MacDonald, M. Hira, T. K. \& Masud, J. 2010. Childhood Consumer Experience And Fianancial Literacy of Students in Malaysia. Familiy And Consumer Sciences Research Journal Vol 38, No 4 June 2010

Seto dan Trizki L. 2012. Financial Parenting: Menjadikan Anak Cerdas dan Cermat Mengelola Uang. Jakarta: Naura Books.

Setyaka, H. 2014. Rahasia Kebiasaan Orangorang Sukses Sejak Bangun Pagi Hingga Sebelum Sarapan. Yogyakarta: DIVAPress

Sujiono, Yuliani Nurani. 2011. Konsep Dasar Pendidikan Anak Usia Dini. Jakarta: Indeks 